\title{
Regulation of Primate Testicular Luteinizing Hormone Receptors and Steroidogenesis
}

\author{
Terry F. Davies, Gary D. Hodgen, Maria L. Dufau, and Kevin J. Catt, \\ Endocrinology and Reproduction Research Branch, and Pregnancy Research \\ Branch, National Institute of Child Health and Human Development, National \\ Institutes of Health, Bethesda, Maryland 20205
}

A B S T RACT The testicular luteinizing hormone $(\mathrm{LH})$ receptors of the rhesus monkey and human have many features in common, including high equilibrium association constant, marked species specificity, and relatively low binding capacity. We have, therefore, used rhesus monkeys as models for human LH-receptor regulation in vivo during gonadotropin treatment. In four adult male monkeys, treated with 10,000 IU human chorionic gonadotropin (hCG), serum and testicular steroidogenic responses were monitored at 24 -h intervals during the following $4 \mathrm{~d}$, and LH-receptor concentrations were measured by ${ }^{125}$ I-hCG binding to 15,000-g particles prepared from testis biopsy specimens. In treated animals, serum hCG was maximal on day 1 at $322 \pm 16 \mathrm{ng} / \mathrm{ml}$ and declined to $24.4 \pm 2.3$ $\mathrm{ng} / \mathrm{ml}$ by day 4 . Serum testosterone was increased threefold during the subsequent $4 \mathrm{~d}$ (from $6.5 \pm 2.0$ to $18.6 \pm 4.4 \mathrm{ng} / \mathrm{ml}$ ) but serum progesterone remained unchanged. In contrast, serum $17 \alpha$-hydroxyprogesterone increased 12 -fold to $5.5 \pm 0.5 \mathrm{ng} / \mathrm{ml}$ at day 1 and was increased fourfold during the subsequent $3 \mathrm{~d}$. The LHreceptor binding capacity of the primate testis was reduced by $18.3 \pm 6.0 \%$ on day $1,51.7 \pm 7.4 \%$ on day 2 , and $45.3 \pm 2.4 \%$ on day 4 . Occupancy of the LH receptors by endogenously bound hCG was significant on day 1 but was negligible by day 4 . These data demonstrate that gonadotropin-induced LH-receptor depletion occurs in the rhesus testis and indicate that primate gonadotropin receptors are susceptible to the regulatory processes recently described in the rat. In addition, the simultaneous and disproportionate accumulation of $17 \alpha$-hydroxyprogesterone indicates that 17,20-desmolase was rate-limiting under these conditions in the primate testis Leydig cell.

Received for publication 19 March 1979 and in revised form 12 June 1979.

\section{INTRODUCTION}

Gonadotropic hormones such as luteinizing hormone $(\mathrm{LH})^{1}$ and human chorionic gonadotropin (hCG) have been shown to diminish gonadal receptors and steroid responses after their initial stimulation of gonadal function. In the rat, Leydig-cell stimulation by exogenous $(1,2)$ or endogenous $(3,4)$ gonadotropin is followed by LH-receptor depletion that is apparent by $24 \mathrm{~h}$, and which may eventually involve over $99 \%$ of gonadal binding sites (5). LH-receptor loss is maximal at $2-3 \mathrm{~d}$, then recovery occurs gradually to normal levels over the next 6-7 d (5). LH-receptor depletion in the rat after exposure to high levels of hCG is also accompanied by biosynthetic defects in the steroidogenic pathway, principally with a reduction in 17,20desmolase activity (6).

Analysis of the human and rhesus monkey LH receptors in testis homogenates and isolated Leydig cells has revealed several features of primate receptors that are distinct from those of the rat (7). In addition to a high equilibrium association constant $\left(K_{\mathrm{a}}=1-2\right.$ $\left.\times 10^{10} \mathrm{M}^{-1}\right)$, the primate $\mathrm{LH}$ receptor exhibited marked species specificity for primate gonadotropins with interstitial-cell-stimulating activity, and had a low binding capacity (23-146 fmol hCG/g) when compared with rodent receptors. These data suggested that rhesus monkeys would be useful models for the analysis of human testis receptor function and, in particular, for studies on primate gonadotropin receptor regulation in vivo. Because it is important to determine whether primate gonadotropin receptors are subject to regulation by homologous hormone, as recently described in laboratory animals, we examined the effects of high doses of hCG upon the testis in adult rhesus monkeys.

\footnotetext{
'Abbreviations used in this paper: BSA, bovine serum albumin; hCG, human chorionic gonadotropin; LH, luteinizing hormone; PBS, phosphate-buffered saline.
} 
Serum and testicular steroidogenic responses were monitored in addition to the testicular LH-receptor concentration in consecutive testis biopsy specimens.

\section{METHODS}

Animals and treatment. Left testicular biopsies were performed under ketamine-induced general anaesthesia on four adult male rhesus monkeys ( $>6 \mathrm{yr}$ ) after basal venous blood samples had been obtained. 10,000 IU hCG (Pregnyl, 2,495 IU/mg by bioassay, Organon Inc., West Orange, N. J.) was administered by intramuscular injection, and subsequent serum samples were obtained at 24 -h intervals over the following $4 \mathrm{~d}$. In addition, on day 1 the left testis was removed, on day 2 the right testis was biopsied, and on day 4 the right testis was removed. Testis tissue was quick-frozen in $0.5-\mathrm{g}$ segments and stored at $-70^{\circ} \mathrm{C}$ until required. With this protocol, each animal served as its own control for both gonadalsteroid and LH-receptor analysis.

Measurement of unoccupied testicular $\mathrm{LH}$ receptors. The presence of testicular LH receptors was determined by assay of specific binding of ${ }^{225} \mathrm{I}-\mathrm{hCG}$ to primate testis homogenate as previously described (7). Briefly, testis was homogenized in ice-cold phosphate-buffered saline (PBS) containing 1 $\mathrm{mg} / \mathrm{ml}$ of bovine serum albumin (BSA) (PBS/BSA) with a ground-glass tissue grinder. A 15,000-g fraction was obtained by centrifugation and used for binding in aliquots of 25-, 50-, and 100-mg equivalents of testis wet weight. Testis fractions were incubated for $16-20 \mathrm{~h}$ at room temperature with $\cong 2 \mathrm{ng}$ of ${ }^{125} \mathrm{I}-\mathrm{hCG}(150,000 \mathrm{cpm})$ previously purified on concanavalin-A (8) in a final volume of $250 \mu \mathrm{l}$. Separation of bound and free hormone was performed by centrifugation at $5,000 \mathrm{~g}$, and the radioactivity bound to pellets was determined in a Searle gamma spectrometer (Searle Diagnostics Inc., Des Plaines, Ill.) with counting efficiency of $70 \%$. Nonspecific binding was assessed by inclusion of 100 IU hCG $(10 \mu \mathrm{g})$ in the incubation mixture. The binding capacity was calculated from the specific activity of the ${ }^{125} \mathrm{I}-\mathrm{hCG}(60,000-75,000 \mathrm{cpm} /$ $\mathrm{ng}$ ) as measured by self-displacement assay (9), corrected for the maximum bindability of the label to rat-testis homogenate (55-75\%), and expressed as the group mean \pm SEM.

Measurement of occupied $L H$ receptors. Testis samples from days 1 and 4 were analyzed for endogenously bound hCG. $1 \mathrm{~g}$ of testis was homogenized in $5 \mathrm{ml}$ of PBS/BSA and centrifuged at $15,000 \mathrm{~g}$ for $30 \mathrm{~min}$. The supernate was retained for estimation of testicular steroid content. The $15,000-\mathrm{g}$ pellet was resuspended in $2 \mathrm{ml}$ of PBS/BSA and heated at $70^{\circ} \mathrm{C}$ for $15 \mathrm{~min}$ to dissociate receptor-bound hCG. The mixture was then recentrifuged, and the hCG content of the supernate was estimated by specific radioimmunoassay. Previous experiments with this technique have demonstrated that $>80 \%$ of receptor-bound ${ }^{125}$ I-hCG is dissociated under these conditions.

Radioimmunoassay. The hCG content of serum and testicular supernates was determined by specific radioimmunoassay which employed antiserum to hCG- $\beta$ (10). Testosterone, $17 \alpha$-hydroxyprogesterone, and progesterone were measured by specific radioimmunoassay after diethyl-ether extraction as previously described (6) except that separation of the 17-hydroxylated steroids was performed by chromatography on Sephadex-LH20 (Pharmacia Fine Chemicals, Inc., Piscataway, N. J.) (11).

\section{RESULTS}

Serum and testicular concentrations of hCG. Administration of 10,000 IU hCG (equivalent to $1 \mathrm{mg}$ purified hCG) was followed by a marked increase in serum hCG which was maximal at $24 \mathrm{~h}$ (mean \pm SEM $=322 \pm 16 \mathrm{ng} / \mathrm{ml}$ ) and declined considerably by day 4 $(24.4 \pm 2.3 \mathrm{ng} / \mathrm{ml})$ (Fig. 1). Measurement of tissue-bound hCG was only possible at the time of orchidectomy (days 1 and 4), giving values of $21.6 \pm 5.2 \mathrm{fmol} / \mathrm{g}$ of testis on day 1 and $7.6 \pm 0.26 \mathrm{fmol} / \mathrm{g}$ on day 4 .

Primate testicular LH-receptor content. The initial binding capacity of the rhesus testes was $59.8 \pm 20.7$ $\mathrm{fmol} / \mathrm{g}$. Administration of hCG caused subsequent inhibition of ${ }^{125}$ I-hCG binding to the testis fractions as illustrated in Fig. 1. Addition of the occupied and free receptor sites, in the samples where dissociable hCG was detected, allowed the calculation of total LHreceptor content for days 1 and 4 as illustrated for a single animal in Fig. 2. The mean data for all four animals indicated that $36.1 \pm 9 \%$ of the $\mathrm{LH}$ receptors were occupied on day 1 and $12.7 \pm 3.5 \%$ on day 4 . Hence, the residual hCG occupancy could not account for the $45 \%$ reduction in hCG binding capacity $4 \mathrm{~d}$ after hCG administration. When compared with the initial binding data, there was a mean $17.8 \%$ increase in $\mathrm{LH}$ receptors on day 1 , before the subsequent decline in receptor content. This rise was not, however, statistically significant for the group as a whole.

Steroidogenic responses in serum and testis. Serum testosterone concentration exhibited a prolonged, threefold increase during the $4 \mathrm{~d}$ after hCG administration, reaching maximum levels at $24 \mathrm{~h}$ (Table I and Fig. 3). Serum progesterone remained unchanged during

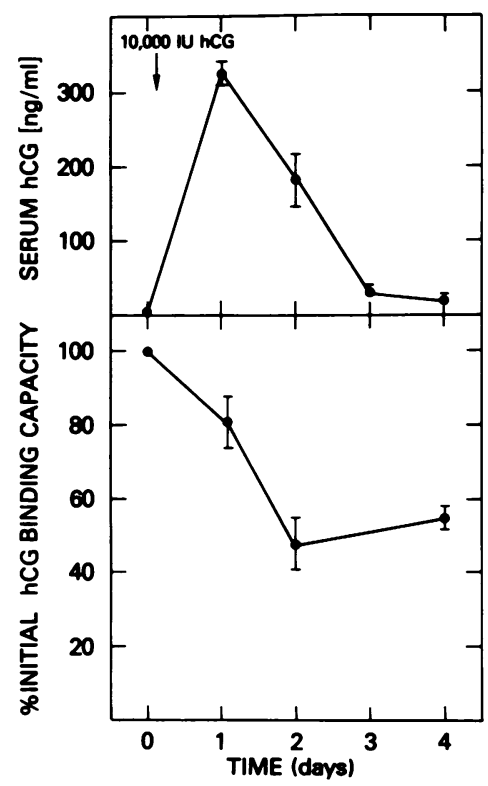

Figure 1 Serum hCG levels (upper panel) and changes in testicular LH-receptor concentration (lower panel) after administration of 10,000 IU hCG to adult rhesus monkeys. Each point represents the mean $\pm S E$ for the group $(n=4)$. 


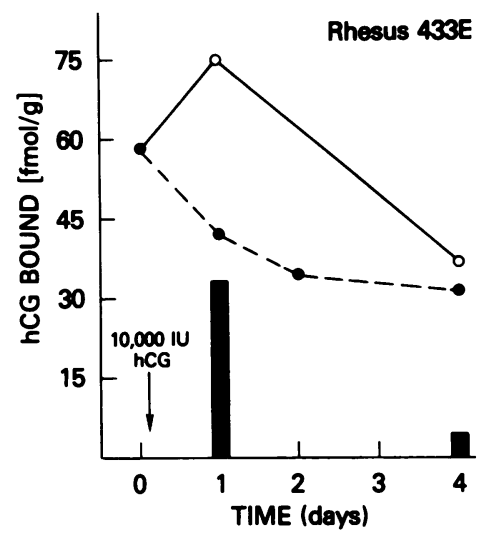

Figure 2 An individual example (Rhesus 433E) of changes in testicular LH-receptor binding capacity and tissue-bound hCG after administration of hCG (10,000 IU). The total testicular LH-receptor concentration (continuous line) was determined by summation of the quantity of available receptors (broken line) and the occupied sites (closed bars) at days 1 and 4 .

this time. In contrast, serum $17 \alpha$-hydroxyprogesterone increased 12 -fold to $5.5 \pm 0.5 \mathrm{ng} / \mathrm{ml}$ by day 1 and remained elevated fourfold throughout the study. Estimation of progesterone, $17 \alpha$-hydroxyprogesterone, and testosterone in the supernates obtained from testis homogenates on days 1 and 4, was also performed and correlated directly with serum levels. Whereas progesterone and testosterone showed no change during this time, the $17 \alpha$-hydroxyprogesterone content declined from day 1 to day 4 (from $163 \pm 26$ to $83 \pm 12.5 \mathrm{ng} / \mathrm{g}$ ).

\section{DISCUSSION}

This study has demonstrated that gonadotropin-induced LH-receptor depletion occurs in the rhesus testis after stimulation by exogenous hCG. The primate gonadotropin receptors are therefore susceptible to the same regulatory processes as recently described in rodents. Occupancy of primate testis LH receptors by hCG occurred rapidly, coincident with peak serum hCG levels, and caused an initial fall in hCG binding capacity. However, serum hCG and receptor occupancy had declined to a low level by day 4 , and the reduced hCG binding capacity of the hCG-treated testes was secondary to extensive loss or inactivation

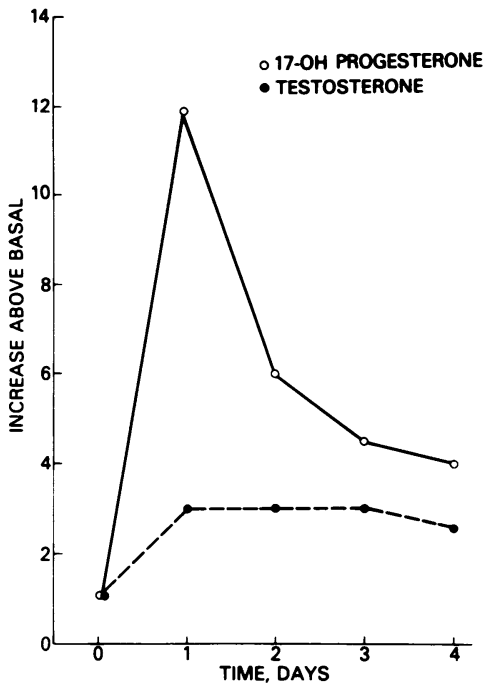

Figure 3 Serial changes in serum testosterone and $17 \alpha$-hydroxyprogesterone after hCG administration (10,000 IU) to adult male rhesus monkeys $(n=4)$. The data are expressed as increases above basal levels (shown in Table I) and represent the mean increases for the group.

of receptor binding sites. In previous studies in the rat, receptor loss has persisted until the 5 th $d(1)$ and, hence, significant recovery was not expected in our investigation.

Analysis of tissue-bound hCG and available hCG binding sites permitted quantitation of the total $\mathrm{LH}$ receptor content of the primate testes after hCG stimulation of the Leydig cells. Occupancy of sites by $24 \mathrm{~h}$ was accompanied by a small increase in total receptor concentration in each of the animals studied. The peak receptor increase may have occurred before the first LH-receptor analysis (12). Such a phenomenon has been a consistent finding in many LH-receptor regulatory studies (13). This possible "unmasking" of Leydig-cell membrane receptors remains of uncertain significance, and its relationship to subsequent receptor depletion requires further clarification.

Exogenous stimulation of Leydig-cell function was followed by a threefold increase in serum testosterone by $24 \mathrm{~h}$ and which persisted throughout the study. This pattern of response was typical of that seen in man (14) and is in marked contrast to the pattern seen in the

TABLE I

Serum Levels of Progesterone, $17 \alpha$-Hydroxyprogesterone, and Testosterone after hCG Administration

\begin{tabular}{|c|c|c|c|c|c|}
\hline Time (days) & 0 & 1 & 2 & 3 & 4 \\
\hline $\begin{array}{l}\text { Progesterone, } n g / m l \\
17-O H \text { progesterone, }\end{array}$ & $1.4 \pm 0.45$ & $2.0 \pm 0.3$ & $1.7 \pm 0.09$ & $1.1 \pm 0.07$ & $1.2 \pm 0.5$ \\
\hline$n g / 100 \mathrm{ml}$ & $45.0 \pm 16$ & $545 \pm 55$ & $270 \pm 25$ & $176 \pm 28$ & $203 \pm 56$ \\
\hline Testosterone, $n g / m l$ & $6.6 \pm 2.1$ & $18.6 \pm 4.5$ & $18.9 \pm 0.7$ & $18.1 \pm 0.8$ & $17.4 \pm 0.75$ \\
\hline
\end{tabular}


laboratory rat, perhaps because of the prolonged halflife of hCG in man when compared with the rat $(15,16)$. Stimulation of the rat testis in vivo leads to a testosterone response within $15 \mathrm{~min}$ and a 5 - to 10 -fold increase by $2-12 \mathrm{~h}$, followed by a decline to normal levels within 1-2 d depending upon the administered dose of gonadotropin $(1,2)$. The serum $17 \alpha$-hydroxyprogesterone response of the hyperstimulated primate testes was similar to the pattern of testosterone response seen in the rat. A peak increase, 12 -fold above basal, was seen at $24 \mathrm{~h}$ with a rapid decline by $48 \mathrm{~h}$. This suggested that the conversion of $17 \alpha$-hydroxyprogesterone to testosterone was the rate-limiting step in the $\Delta_{4}$-steroid biosynthetic pathway, a conclusion supported by the serum and testicular progesterone contents. Steroid biosynthetic abnormalities have previously been detected in desensitized rat Leydig cells both in vitro (6) and in vivo (17). In the rat, there was a marked decrease in 17,20-desmolase (or lyase) enzyme activity after LH stimulation, which lead to accumulation of steroid precursors above this step in the biosynthetic pathway. The rapid accumulation of serum and testicular $17 \alpha$-hydroxyprogesterone in our study would be consistent with this step becoming ratelimiting in the desensitized rhesus monkey testis. This could result from an enzymatic lesion as demonstrated in rat Leydig cells, or may simply be the result of enzyme saturation by maximally enhanced precursor formation. Differentiation between these mechanisms requires further study of the enzymatic capacity of the desmolase step during gonadotropin-stimulated steroidogenesis in primate testes. Increased secretion of 17-hydroxylated steroids was not apparent after lowdose hCG stimulation of human testes in vivo $(18,19)$ and in vitro (unpublished observations), but has been recently noted after repeated hCG administration in man (20).

The interstitial cells of man are probably onlỳ rarely exposed to the high concentrations of gonadotropin used in this study. However, it has been suggested that men with hCG-secreting choriocarcinoma may have desensitized Leydig cells, to explain their normal testosterone secretion. Our study, with a single dose of hCG, suggests that such an explanation is tenable after more chronic exposure. Furthermore, our data on desensitization of the primate $\mathrm{LH}$ receptor enhances the possibility of such a mechanism having a physiological role in the control and maintenance of human gonadal function. These data further suggest that negative regulation of ovarian and testicular function by gonadotropin-releasing hormone and its analogues $(3,4)$ should also be effective in man, an approach that offers interesting possibilities for fertility control.

\section{REFERENCES}

1. Hsueh, A. J. W., M. L. Dufau, and K. J. Catt. 1976. Regulation of luteinizing hormone receptors in testicular inter- stitial cells by gonadotropin. Biochem. Biophys. Res. Commun. 72: 1145-1152.

2. Sharpe, R. M. 1976. hCG-induced decrease in availability of rat testis receptors. Nature (Lond.). 264: 644-646.

3. Auclair, C., P. A. Kelly, D. H. Coy, A. V. Schally, and F. Labrie. 1977. Potent inhibitory activity of (D-Leu ${ }^{6}$, DesGly- $\mathrm{NH}_{2}{ }^{10}$ ) LHRH ethylamide on LH/hCG and prolactin receptor levels in the rat. Endocrinology. 101: 1890-1893.

4. Catt, K. J., A. J. Baukal, T. F. Davies, and M. L. Dufau. 1979. Luteinizing hormone-releasing hormone-induced regulation of gonadotropin and prolactin receptors in the rat testis. Endocrinology. 104: 17-25.

5. Hsueh, A. J. W., M. L. Dufau, and K. J. Catt. 1977. Gonadotropin-induced regulation of luteinizing hormone receptors and desensitization of testicular $3^{\prime}: 5^{\prime}$-cyclic AMP and testosterone responses. Proc. Natl. Acad. Sci. U. S. A. 74: 592-595.

6. Cigorraga, S. B., M. L. Dufau, and K. J. Catt. 1978. Regulation of luteinizing hormone receptors and steroidogenesis in gonadotropin-desensitized Leydig cells. J. Biol. Chem. 253: 4297-4304.

7. Davies, T. F., P. C. Walsh, G. D. Hodgen, M. L. Dufau, and K. J. Catt. 1979. Characterization of the primate LH receptor in testis homogenates and Leydig cells. J. Clin. Endocrinol. Metab. 48: 680-685.

8. Dufau, M. L., T. Tsuruhara, and K. J. Catt. 1972. Interaction of glycoprotein hormones with agarose-Concanavalin A. Biochim. Biophys. Acta 278: 281-285.

9. Catt, K. J., J-M. Ketelslegers, and M. L. Dufau. 1976. Receptors for gonadotropic hormones. In Methods in Receptor Research. M. Blecher, editor. Marcel Dekker, New York. 1: 175-250.

10. Odell, W. D., G. T. Ross, and P. L. Rayford. 1967. Radioimmunoassay for luteinizing hormone in human plasma or serum: physiological studies.J. Clin. Invest. 46: 248-255.

11. Carr, B. R., G. Mikhail, and G. L. Flickinger. 1971. Column chromatography of steroids on Sephadex LH-20.J. Clin. Endocrinol. Metab. 33: 358-360.

12. Huhtaniemi, I., H. Martikainen, and L. Tikkala. 1978. hCG-induced changes in the number of rat testis LH/hCG receptors. Mol. Cell. Endocr. 11: 43-50.

13. Harwood, J. P., M. Conti, P. M. Conn, M. L. Dufau, and K. J. Catt. 1978. Receptor regulation and target cell responses: studies in the ovarian luteal cell. Mol. Cell. Endocr. 11: 121-135.

14. Jones, T. M., V. S. Fang, R. L. Landau, and R. Rosenfield. 1978. Direct inhibition of Leydig cell function by estradiol. J. Clin. Endocrinol. Metab. 47: 1368-1373.

15. Rizkallah, T., E. Gurpide, and R. L. V. Wiele. 1969. Metabolism of hCG in man. J. Clin. Endocrinol. Metab. 29: 92-100.

16. Braunstein, G. D., J. L. Vaitukaitis, and G. T. Ross. 1972. The in vivo behaviour of human chorionic gonadotropin after dissociation into subunits. Endocrinology. 91: 10301036.

17. Belanger, A., C. Auclair, C. Seguin, P. A. Kelly, and F. Labrie. 1979. Down-regulation of testicular androgen biosynthesis and LH levels by an LHRH agonist: role of prolactin. Mol. Cell. Endocr. 13: 47-53.

18. Strott, C. A., T. Yoshimi, and M. B. Lipsett. 1969. Plasma progesterone and 17-hydroxyprogesterone in normal men and children with congenital adrenal hyperplasia. J. Clin. Invest. 48: 930-939.

19. Ruder, H. J., D. L. Loriaux, R. J. Sherins, and M. B. Lipsett. 1974. Leydig cell function in men with disorders of spermatogenesis. J. Clin. Endocrinol. Metab. 38: 244247.

20. Glass, A. R. 1979. Endocrine Society 61st Annual Meeting. 832. (Abstr.) 